\title{
Specificity of cues inducing defensive spines in the bryozoan Membranipora membranacea
}

\author{
Erika V. Iyengar*, C. Drew Harvell \\ Department of Ecology and Evolutionary Biology, Cornell University, Ithaca, New York 14853, USA
}

\begin{abstract}
Although theory pinpoints the reliability of cues as an important condition for the evolution of inducible defenses, the specificity of cues is poorly known in most systems. The bryozoan Membranipora membranacea produces long, energetically-costly spines in response to a trophically specialized nudibranch Doridella steinbergae, but the range of nudibranchs that trigger this response is unknown. We tested chemical cues from 14 nudibranch species from 4 suborders, the snail species Lacuna vincta, and an abiotic treatment (desiccation) for their ability to induce spines. Both corner spines (arising from the corners of the zoecium) and membranous spines (arising from the frontal membrane of the zooid) were observed. Of the nudibranch species tested, $57 \%$ induced corner spines in at least 1 trial: 4 predators of M. membranacea (Onchidoris muricata, Polycera zosterae, Triopha catalinae, and D. steinbergae) and 4 non-predators (Coryphella sp., Archidoris odhneri, Cadlina luteomarginata, and Dirona albolineata). Although many nudibranchs occasionally triggered spines, the spine response was most reliably and fully developed in response to the bryozoan's primary predator, D. steinbergae. All other species that induced corner spines, except Coryphella sp., failed to induce spines in all trials. Membranous spines were sometimes produced in response to $D$. steinbergae, O. muricata, P. zosterae, A. odhneri, and Coryphella sp. The last 2 species are not known to prey on M. membranacea. Neither corner nor membranous spines were ever induced by Discodoris sandiegensis, Dendronotus frondosus, Dendronotus diversicolor, Tritonia festiva, Flabellina trilineata, Phidiana crassicornis, or desiccation. Of these non-inducers, only P. crassicornis feeds on M. membranacea, and this species typically causes little damage. There was no phylogenetic pattern among nudibranchs inducing spines. The production of corner and membranous spines were correlated. Corner spines appeared to have a lower induction threshold than membranous spines; the latter are therefore a more conservative indication of induction. Counter to the hypothesis of Adler \& Grünbaum, the spine-inducing chemical cue(s) from $D$. steinbergae is probably not a mating pheromone, as $D$. steinbergae egg masses and pre-reproductive slugs induced spines. We conclude that $M$. membranacea often produces spines in response to predators that are deterred by spines, but seems surprisingly responsive to cues from some benign nudibranch species.
\end{abstract}

KEY WORDS: Chemical ecology $\cdot$ Defense $\cdot$ Nudibranch predators $\cdot$ Bryozoans

\section{INTRODUCTION}

Some plants, invertebrates and vertebrates can rapidly develop morphological defenses after receiving cues from herbivores, predators and competitors (Adler \& Harvell 1990, Harvell 1990a, Karban \& Baldwin 1997, Tollrian \& Harvell 1999a, Agrawal et al.

*E-mail: evc3@cornell.edu
2000). These inducible defenses are widespread (reviewed in Baldwin 1996, Tollrian \& Harvell 1999a) and include structural changes in protozoans (Kuhlmann \& Heckmann 1985), plants (Karban \& Meyers 1989), hydroids (Gaulin et al. 1986), rotifers (Gilbert 1966, Gilbert \& Stemberger 1984), molluscs (Appleton \& Palmer 1988, Leonard et al. 1999), cladocerans (Dodson 1989, Havel 1987), bryozoans (Harvell 1984), and barnacles (Lively 1986). Physiological costs of

() Inter-Research $2002 \cdot$ www.int-res.com 
defense have been shown in many interactions (McCollum \& Van Buskirk 1996, Zangerl et al. 1997, others reviewed in Tollrian \& Harvell 1999a). It has been proposed that balancing these costs and benefits in environments with fluctuating predation risks has driven the evolution of inducible rather than constitutive defenses, creating defenses triggered specifically by imminent predators (Harvell 1986, Harvell 1990a, Agrawal et al. 1999, Harvell \& Tollrian 1999). Theoretical work on the evolution of phenotypic plasticity pinpoints the reliability of induction cues and the ability of cues to accurately reflect the selective environment of the near future as significant constraints (Levins 1963, Bradshaw 1965, Lloyd 1984, Moran 1992). Lively et al. (2000) and Harvell (1998) have studied the responses of prey (barnacles and bryozoans, respectively) to different concentrations of the same cue. Kuhlmann \& Heckmann (1985) observed the responses of a protozoan to multiple predatory species. But for many systems, the reliability of the cue, the degree of specificity, and the flexibility of these inducible responses are not known (Harvell 1990a, Tollrian \& Harvell 1999b). Moran's model (1992) predicts that a process of phenotype-environment matching drives the evolution of highly specific cues where possible. Highly specific responses resulting in appropriately deployed defenses should be evolutionarily advantageous, so we predicted that the bryozoan Membranipora membranacea would distinguish among the repertoire of predatory and benign nudibranch species before initiating its defense response. Yet Adler \& Grünbaum (1999) emphasize the co-evolutionary arms race and the evolutionary forces that push the predator to obscure itself from prey recognition. This arms race may result in a mismatch between the bryozoan's perceived and actual risk, resulting in incorrect deployment of the defense.

In the San Juan Archipelago, Washington, USA, the encrusting cheilostome bryozoan Membranipora membranacea lives for roughly 4 mo (end of May to September), and its asexual reproduction results in circular colonies of increasing diameter (if growth is unimpeded). Individual zooids of these colonies produce permanent chitinous corner and membranous spines (Harvell 1984) within $48 \mathrm{~h}$ of exposure to a waterborne chemical cue from their main predator, the nudibranch Doridella steinbergae (Harvell 1984, 1986, 1992). Corner spines are produced from existing buds at the corner of each zoecium, while membranous spines arise directly from the zooid frontal membrane (Harvell 1984). Only zooids within a certain age range are competent to produce spines (Harvell 1991) and the stimulus of the inducing cue is graded (length of spines increases with greater exposure until a saturation point is reached; Harvell 1990b, 1992, 1998).
These spines effectively deter feeding by $D$. steinbergae (Harvell 1986, Nowlis 1994).

Colony area and fecundity are correlated in Membranipora membranacea, as all zooids can potentially reproduce sexually (Harvell 1986, 1992). Therefore, there should be strong selection pressure to minimize the loss of zooids. But spine formation is costly, resulting in slower colony growth rate while spines are formed (Harvell 1986, 1992) and less effective feeding currents after spine formation (Grünbaum 1997). Because of these costs and because many species of nudibranchs (predatory and benign) co-occur with M. membranacea, there should be a selective advantage for colonies that can discriminate between threatening and benign situations, producing spines only when predators are nearby. Although spine production by M. membranacea in response to Doridella steinbergae has been studied extensively in the laboratory, the degree of specificity of the defense response to other nudibranch cues is unknown. Yoshioka (1982) noticed that spines in $M$. membranacea correlated with the presence of Corambe pacifica (another specialist on M. membranacea); Harvell (1984) recorded that the nudibranch Onchidoris muricata (a bryozoan generalist) induced membranous spines at a rate comparable with that of D. steinbergae. No other species have been tested. Additionally, it is unknown whether corner and membranous spines play different functional roles in defense. Therefore, we wanted to determine whether M. membranacea would always produce both types of spines after receiving a stimulatory cue or whether 1 type of spine was more likely to be produced.

Published diets of nudibranchs are often not specific in terms of the species consumed, but rather list 'bryozoans' as a potential prey group. Our studies depend on whether certain nudibranch species are predators of Mebranipora membranacea specifically. Therefore, for a subset of the nudibranch species used in the chemical cue induction experiments, we determined whether they would prey on $M$. membranacea, given no other food source. The type of damage inflicted by a predator may dictate whether defense spines are an effective deterrent, so any type of damage caused by a nudibranch predator was qualitatively recorded.

Little is known about the co-evolutionary dynamics of prey and predator, but Adler \& Grünbaum (1999) proposed that an evolutionary constraint may prevent the induction cue of Doridella steinbergae from becoming unrecognizable to Membranipora membranacea. One hypothesis is that the D. steinbergae cue is a mating pheromone, restricted in evolutionary lability by the required recognition by the opposite sex (Adler \& Grünbaum 1999). Because mating pheromones would only be produced by larger, sexually mature individuals, one test of this mating pheromone hypo- 
thesis is to compare induction by reproductive and non-reproductive D. steinbergae.

In the studies reported herein, we tested 5 interrelated hypotheses. By exposing Membranipora membranacea colonies to chemical cues from 14 species of common nudibranchs, we investigated the specificity of the inducible defense response in $M$. membranacea. We used nudibranch predators of $M$. membranacea and benign, non-predatory nudibranchs to investigate whether $M$. membranacea's cue specificity matches its risk. We predicted that (1) only nudibranch species that were predators of $M$. membranacea would induce spines. We further predicted that (2) if any non-predatory nudibranch species caused spine induction, those nudibranchs would be closely related to the specialist predator Doridella steinbergae (Doridacea), and thus trigger spine induction through phylogenetically driven cue similarities. Phylogenetic trends in cue specificity were assessed by including nudibranchs from 4 suborders. For a subset of the nudibranch species, we (3) tested whether they would eat M. membranacea, given no other food source. This was done to verify the predicted predation risk to $M$. membranacea by the various nudibranch species. We used the results of the above experiments to evaluate (4) whether production of corner and membranous spines are correlated or whether 1 spine type can be produced without the other. Finally, we examined spine induction by 3 size classes and egg masses of the known specialist D. steinbergae to evaluate the hypothesis that (5) the spine-inducing chemical of this species is a mating pheromone.

\section{MATERIALS AND METHODS}

Spine induction protocol. Research was conducted at the Friday Harbor Laboratories in the San Juan Islands, Washington, during July 1996, and June and July 1997. Membranipora membranacea colonies on Laminaria groenlandica kelp blades were haphazardly selected by snorkeling. Blades were brought into the laboratory, and individual undamaged colonies were excised on kelp squares and then placed in running sea water overnight to allow cut kelp edges to heal. As defense response is proportional to colony diameter (Harvell 1991), we restricted the size range of colonies used (90\% of colonies were 1.0 to $2.6 \mathrm{~cm}$ in diameter). Colonies were allocated arbitrarily within treatments. Before experiments were conducted, each colony was checked under a dissecting microscope to ensure that the colony was healthy, unspined, and free of nudibranchs.

Preparation of inducer: Induction water (hereafter referred to as inducer) was prepared by holding test species of nudibranchs for approximately $6 \mathrm{~h}$ in a $3 \mathrm{l}$ vessel of prefiltered seawater (bag filter, pore size $5 \mu \mathrm{m}$ or membrane filter, pore size $0.45 \mu \mathrm{m}$ ). Because nudibranchs that have been feeding on Doridella steinbergae could cause bryozoan spine induction through waste products containing cues from $D$. steinbergae, all nudibranchs were kept for at least $2 \mathrm{~d}$ in the laboratory before use in experiments. At least 50 live Doridella steinbergae of varying sizes were used per 31 seawater to ensure maximal spine response in the large-stimulus induction control (as few as 3 live nudibranchs in 11 of seawater can induce maximal spine response; Harvell 1998). Nowlis (1994) reported field densities for $D$. steinbergae of ca $20 \mathrm{~m}^{-2}$ during the majority of the summer, with a maximum density of ca $60 \mathrm{~m}^{-2}$. As a non-stimulus control, 31 filtered seawater were used in 1996; 50 Lacuna vincta snails (a co-occurring gastropod known not to induce spines) were used per 31 filtered seawater to prepare inducer in 1997.

We exposed Membranipora membranacea colonies to the chemical cues of 14 nudibranch species from 11 families in 4 suborders, both predators (predicted to induce spines) and non-predators (predicted not to induce spines) (Table 1). The nudibranch species varied in their likelihood to interact with $M$. membranacea. Tested species that probably do not regularly contact the bryozoan in this area (due to either depth differences or preferred prey) include Archidoris odhneri, Cadlina luteomarginata, Dendronotus diversicolor, Dirona albolineata, Discodoris sandiegensis, and Tritonia festiva. Although the concentration of nudibranchs in each vessel varied (Table 1), the mass of nudibranchs usually equaled, or exceeded, the approximate mass of the 50 Doridella steinbergae used. To determine whether the spineinducing chemical cue of $D$. steinbergae varies with predator reproductive state (i.e. is a mating pheromone), 3 size classes of this species (small pre-reproductive slugs up to $3 \mathrm{~mm}$ long, medium slugs 3 to $5 \mathrm{~mm}$ long, and large, reproductive slugs 6 to $12 \mathrm{~mm}$ long; Bickell 1978) and D. steinbergae egg masses were tested for their ability to induce spines. M. membranacea has also been reported to produce spines in response to some hydrodynamic environments (Harvell 1994): forked spines in still water (C. D. Harvell \& G. Trager unpubl. data) and possible spine induction after a few hours of desiccation (Harvell pers. obs.). For this reason, a desiccation treatment (keeping colonies out of water for $1 \mathrm{~h}$ once a day on all days that other trials received chemical cue) was used to control for any culture conditions that may have contributed to spine induction.

Experimental design: Inducer was passed through a coarse filter (holes smaller than the nudibranchs) into 
Table 1. Nudibranch species used in spine induction trials. Information adapted from Behrens (1980), Farmer (1980), McDonald \& Nybakken (1980), and pers. obs.

\begin{tabular}{|c|c|c|c|c|c|}
\hline \multirow{3}{*}{$\begin{array}{l}\text { Species used in this study } \\
\begin{array}{l}\text { Doridella steinbergae } \\
\text { (Positive control) }\end{array}\end{array}$} & \multirow{2}{*}{ Suborder } & \multirow[t]{2}{*}{ Family } & \multirow[t]{2}{*}{ Diet } & \multicolumn{2}{|c|}{ Concentration in inducer $\left(\mathrm{l}^{-1}\right)$} \\
\hline & & & & Date & No. \\
\hline & Doridacea & Corambidae & The bryozoan Membranipora & \multicolumn{2}{|c|}{ Always $\sim 16.67$} \\
\hline Archidoris odhneri & & Archidorididae & Sponges & $\begin{array}{l}\text { 19 July } 96 \\
\text { 26 July } 96 \\
\text { 30 June } 97 \\
\text { 30 June } 97 \\
\text { 22 July } 97 \\
\text { 22 July } 97\end{array}$ & $\begin{array}{l}1 \\
1.67 \\
0.67 \\
0.67 \\
1 \\
0.67\end{array}$ \\
\hline $\begin{array}{l}\text { Discodoris (formerly } \\
\text { Dialula) sandiegensis }\end{array}$ & & Discodorididae & Sponges & $\begin{array}{l}22 \text { July } 97 \\
22 \text { July } 97\end{array}$ & $\begin{array}{l}2 \\
2\end{array}$ \\
\hline Cadlina luteomarginata & & Dorididae & Sponges & $\begin{array}{l}19 \text { July } 96 \\
\text { 26 July } 96 \\
\text { 30 June } 97\end{array}$ & $\begin{array}{l}2 \\
2.33 \\
2.67\end{array}$ \\
\hline Onchidoris muricata & & Onchidorididae & $\begin{array}{l}\text { Bryozoans, including } \\
\text { Membranipora }\end{array}$ & $\begin{array}{l}\text { 26 July } 96 \\
\text { 19 June } 97 \\
5 \text { July } 97 \\
\text { 12 July } 97 \\
\text { 22 July } 97\end{array}$ & $\begin{array}{l}2.67 \\
5 \\
4.67 \\
4.33 \\
5\end{array}$ \\
\hline Polycera zosterae & & Polyceratidae & $\begin{array}{l}\text { Bryozoans, including } \\
\text { Membranipora }\end{array}$ & $\begin{array}{l}19 \text { June } 97 \\
12 \text { July } 97 \\
22 \text { July } 97\end{array}$ & $\begin{array}{l}9 \\
2 \\
2\end{array}$ \\
\hline $\begin{array}{l}\text { Triopha catalinae } \\
\text { (formerly T. carpenteri) }\end{array}$ & & & $\begin{array}{l}\text { Bryozoans, including } \\
\text { Membranipora }\end{array}$ & $\begin{array}{l}\text { 19 July } 96 \\
\text { 26 July } 96 \\
\text { 30 June } 97 \\
\text { 22 July } 97 \\
\text { 22 July } 97\end{array}$ & $\begin{array}{l}1.67 \\
2.33 \\
1.67 \\
1.67 \\
1.67\end{array}$ \\
\hline Coryphella sp. (rufescens?) & Aeolidacea & Flabellinidae & Hydroids & $\begin{array}{l}19 \text { June } 97 \\
5 \text { July } 97\end{array}$ & $\begin{array}{l}2.33 \\
3\end{array}$ \\
\hline Flabellina trilineata & & & Hydroids & $\begin{array}{l}\text { 19 June } 97 \\
5 \text { July } 97 \\
\text { 12 July } 97\end{array}$ & $\begin{array}{l}5 \\
2 \\
3\end{array}$ \\
\hline $\begin{array}{l}\text { Phidiana (formerly } \\
\text { Hermissenda) crassicornis }\end{array}$ & & Facelinidae & $\begin{array}{l}\text { Hydroids, sea pens, } \\
\text { Opisthobranchs }\end{array}$ & $\begin{array}{l}26 \text { July } 96 \\
19 \text { June } 97 \\
5 \text { July } 97\end{array}$ & $\begin{array}{l}1.67 \\
4 \\
3.67\end{array}$ \\
\hline Dendronotus frondosus & Dendronotacea & Dendronotidae & Hydroids, bryozoans & $\begin{array}{l}30 \text { June } 97 \\
5 \text { July } 97\end{array}$ & $\begin{array}{l}1.67 \\
2.33\end{array}$ \\
\hline Dendronotus diversicolor & & & Hydroids & $\begin{array}{l}\text { 19 July } 96 \\
22 \text { July } 97\end{array}$ & $\begin{array}{l}1 \\
4\end{array}$ \\
\hline Tritonia festiva & & Tritoniidae & $\begin{array}{l}\text { Sea pens, gorgonians, } \\
\text { octocorals }\end{array}$ & $\begin{array}{l}30 \text { June } 97 \\
5 \text { July } 97\end{array}$ & $\begin{array}{l}1.33 \\
1.33\end{array}$ \\
\hline Dirona albolineata & Arminacea & Dironidae & $\begin{array}{l}\text { Bryozoans, prosobranchs, } \\
\text { hydroids, small crustaceans, } \\
\text { sponges, barnacles, tunicates }\end{array}$ & $\begin{array}{l}19 \text { July } 96 \\
26 \text { July } 96\end{array}$ & $\begin{array}{l}1 \\
0.67\end{array}$ \\
\hline
\end{tabular}

the experimental jar. All replicates were held in an environmental chamber at $15^{\circ} \mathrm{C}$ to control temperature and light. Between experiments the vessels and jars were scrubbed with tap water, allowed to dry, and then haphazardly allocated to new treatments.

For each trial, 10 bryozoan colonies were placed on a rack in a 31 treatment jar. Inducer was changed twice daily, with $30 \mathrm{ml}$ of dense (logarithmic growth phase) Rhodomonas sp. (cryptophyte) added daily as food. Inducer was added for $3 \mathrm{~d}$, and colonies were censused on the fifth day. The longest spine from the first functional zooid (near the colony outer perimeter) in each of the 4 quadrants of the colony, plus the second longest spine from the last quadrant, were measured using a dissecting microscope with a micrometer. The average of the 5 longest spines was used as the corner spine length for the colony, so that each trial had 10 replicate values, 1 from each colony. Sampling the 5 longest spines from a colony is a reasonable predictor of the spination state of a colony (Harvell 1998). There 
was usually not a large amount of variation in the lengths of the 5 longest spines within a colony. The outermost ring of functional zooids was scored for membranous spines using a categorical scale of 0 to 2 (0 indicated no membranous spines; 1 indicated scattered, short membranous spines-probably an ineffective defense against Doridella steinbergae; and 2 indicated long membranous spines along the entire perimeter of the colony-probably an effective defense against $D$. steinbergae).

Data analysis: Each week at least 1 large-stimulus control (Doridella steinbergae) and 1 non-stimulus control (Lacuna vincta in 1997, filtered water in 1996) were used. Induction in large-stimulus controls varied significantly between weeks. Since not all species were tested in all weeks, experimental replicates were compared with the non-stimulus and large-stimulus controls of their respective weeks. In the weeks where size classes of $D$. steinbergae were tested separately, large $D$. steinbergae was considered the large-stimulus control.

In 1997, a separate vessel of inducer was prepared for each experimental jar (i.e. if there were 2 replicate jars of Triopha catalinae within the same week, there were 2 inducer vessels with independent nudibranchs) and the jars were treated statistically as 2 separate treatments - see 'Data analysis' below. In 1996, pooled inducer was split between 2 experimental jars. To control for pseudoreplication, results from the 2 jars receiving the same inducer were combined in the analysis for a total of 20 colonies per replicate, rather than the normal 10.

Inducer prepared from different nudibranchs of the same species can cause different induction responses (see 'Results'). To show this variability, independent trials of the same nudibranch species were analyzed separately. Transformations of the data could not eliminate heteroscedasticity. Therefore, nonparametric statistical tests were used. Pairwise pre-planned comparisons of each nudibranch species against the large-stimulus and non-stimulus controls were performed to determine whether a species caused spine formation (result compared with the non-stimulus control) and whether the effect was as great as that induced by the specialist predator (result compared with the large-stimulus control). Kruskal-Wallis tests using SYSTAT version 5.2 (Systat Inc. Evanston, IL) were performed on the corner spine data. Wilcoxon rank sum tests, using StatXact (Cytel Software Corporation, Cambridge, MA) to correct for small sample sizes, were performed on membranous spine data if there were 3 categories of response, and Fisher's exact tests (using StatXact) were performed if there were only 2 categories of responses. Bonferroni alpha level corrections were applied to obtain a family sig- nificance level of $95 \%$. However, in cases where more than 10 comparisons were made simultaneously, we limited the lowest individual alpha level requirement to 0.005 ; requiring alpha levels below this point can obscure true induction responses, i.e. we chose a trade-off between Type I and Type II error.

Predators of Membranipora membranacea and damage inflicted. In order to verify predicted predation risks to Membranipora membranacea, a subset of the nudibranch species used in the spine induction experiments was tested for willingness to consume the bryozoan, given no other food source. The species tested were Dendronotus frondosus, Discodoris sandiegensis, Dirona albolineata, Doridella steinbergae, Phidiana crassicornis, Onchidoris muricata, Polycera zostera, Triopha catalinae, and Tritonia festiva; at least 3 individuals were observed from each species. Individual predators were held in tanks for at least $24 \mathrm{~h}$ before use in the assays. During the assay, predators were placed in separate fingerbowl dishes with healthy, intact $M$. membranacea colonies. After 3 to $4 \mathrm{~d}$, the location and characteristics of any colony damage were recorded.

\section{RESULTS}

\section{Predators of Membranipora membranacea and damage inflicted}

The previously published diets of the nudibranch species used in spine induction experiments are recorded in Table 1. Nudibranchs that are reported to feed on bryozans do not necessarily consume Membranipora membranacea. Additionally, the nudibranch's method of feeding may render ineffective any spines produced by the bryozoan. Therefore, a subset of these species was observed to determine whether they would eat $M$. membranacea and the type of damage they inflicted. Tritonia festiva, Dirona albolineata, Dendronotus frondosus, and Discodoris sandiegensis never fed on M. membranacea. This is consistent with published diets for these species (Table 1). Doridella steinbergae of all sizes, Triopha catalinae, Polycera zostera, Onchidoris muricata, and Phidiana crassicornis fed on M. membranacea and the resulting damage varied (Fig. 1). D. steinbergae (Fig. 1A), O. muricata (Fig. 1B), and P. zosterae (Fig. 1C) ate the polypide, leaving zoecium walls intact, although $P$, zosterae sometimes also destroyed the walls. In comparison, $T$. catalinae cleared a path through the colony, consuming the polypide and zoecium walls (Fig. 1D). P. crassicornis (Fig. 1E) fed only on the outer colony edge (pre-zooids), causing minimal colony area loss. 
A. Doridella steinbergae predation

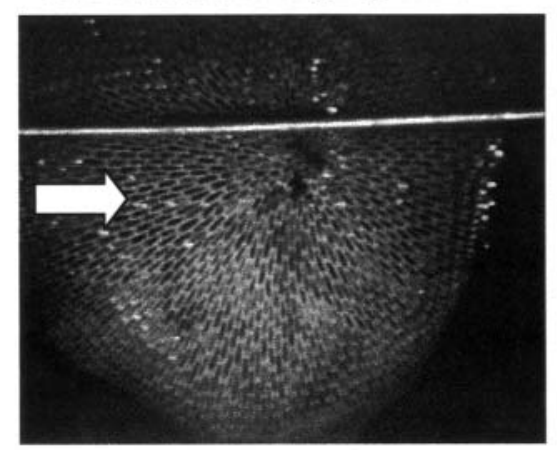

B. Onchidoris muricata predation

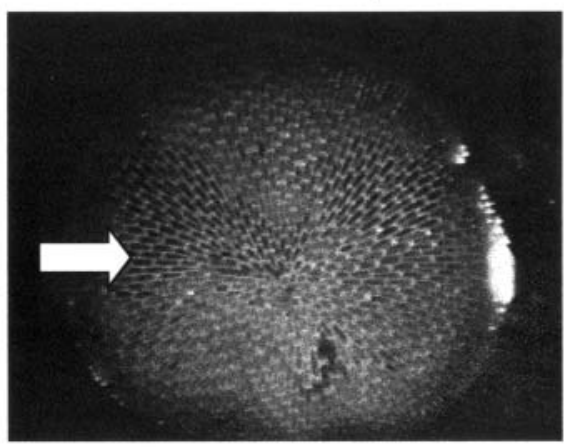

C. Polycera zosterae predation

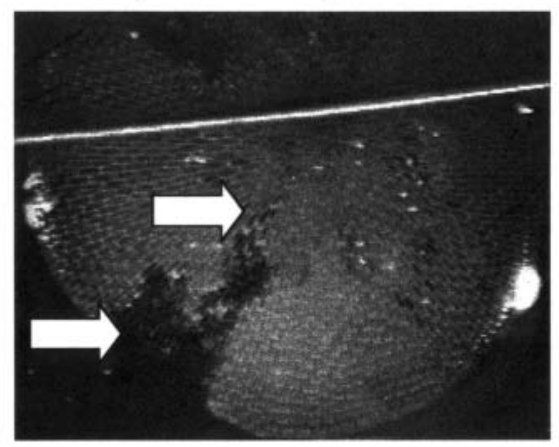

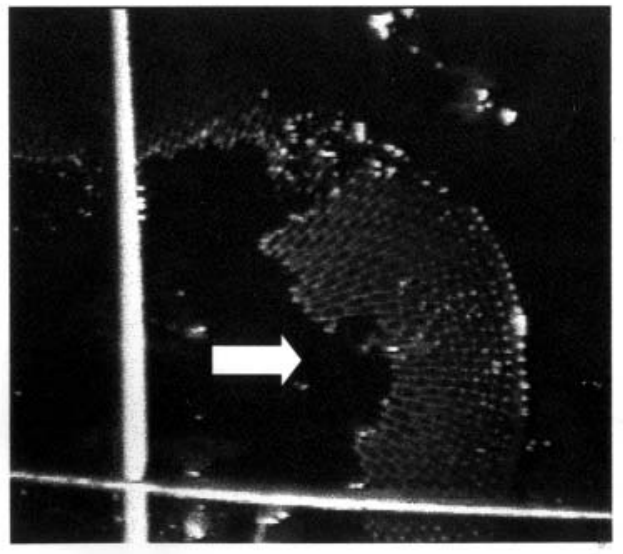

D. Triopha catalinae predation

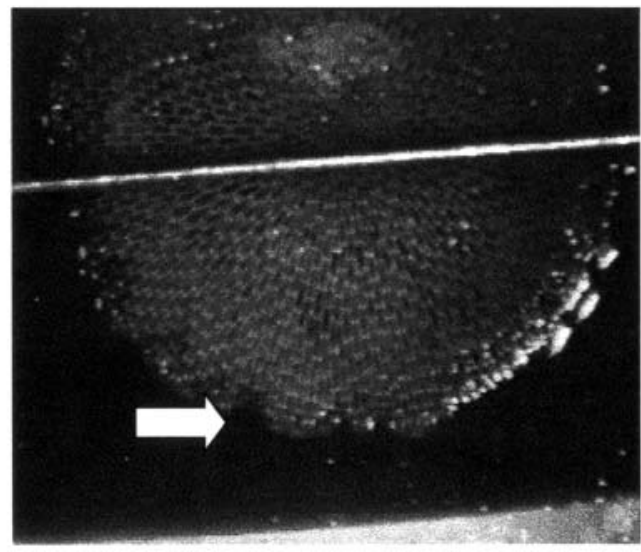

E. Phidiana crassicornis predation

Fig. 1. Predation on Membranipora membranacea colonies by different nudibranch species. White arrows point to evidence of predation. Doridella steinbergae (A) and Onchidoris muricata (B) eat the polypides from individual zooids. Polycera zosterae (C) eats polypides but sometimes removes zooidal walls. Triopha catalinae (D) 'steamshovels' through the bryozoan colony, removing all parts of the bryozoan. Phidiana crassicornis (E) feeds along the edge of the colony and does not substantially reduce colony area. The silver bar in A, C, D and E is a metal pin

\section{Spine induction: specificity of cue}

Induction by non-stimulus and large-stimulus controls

The large-stimulus control, Doridella steinbergae, always induced corner spines that were significantly longer than those in the non-stimulus control (Fig. 2), but the length of corner spines induced varied significantly between trial weeks. This between-week variation forced all statistical comparisons to be limited within weeks rather than across all trials. The length of corner spines induced by the non-stimulus control treatment did not vary significantly between weeks (always 0 or small). Nudibranch species were considered to induce corner spines if the replicate had significantly longer spines than the non-stimulus control. The magnitude of the induction was then compared with that of the large-stimulus control.

Membranous spines were categorized as follows: $0=$ not present; 1 = present but probably ineffective (scattered or very small); and $2=$ present and potentially effective against Doridella steinbergae (many long spines). A trial was considered to result in membranous spines if the bryozoan colonies produced significantly longer membranous spines than the colonies in the non-stimulus control. In 2 experiments (19 July 96, 26 July 96), the large-stimulus control did not induce significantly longer membranous spines than the nonstimulus control and all nudibranch species tested induced membranous spines indistinguishable from either control (Fig. 3). In the other 5 experiments (all conducted in 1997) the large-stimulus control (D. steinbergae) induced significantly longer membranous spines than the non-stimulus control; for the rest of the membranous spine data analyses we considered only the latter 5 experiments.

\section{Induction by non-predatory nudibranchs}

Most nudibranch species that do not feed on Membranipora membranacea failed to induce either corner 


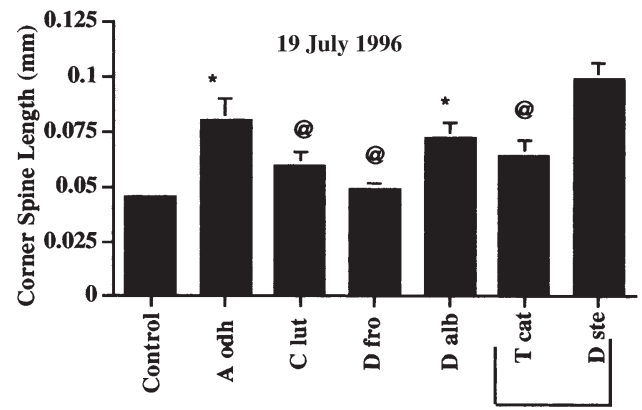

Nudibranch species

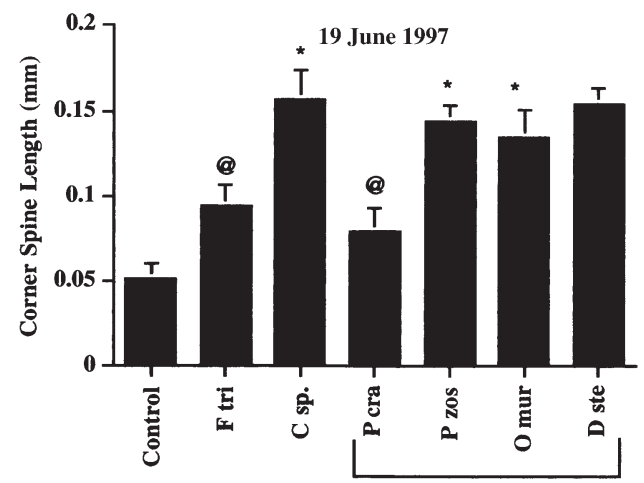

Nudibranch species

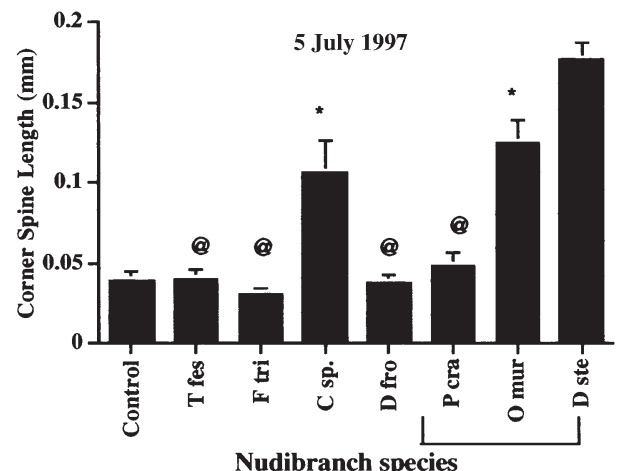

Nudibranch species

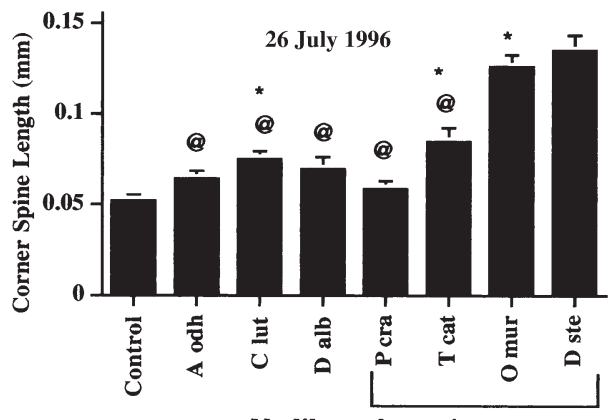

Nudibranch species

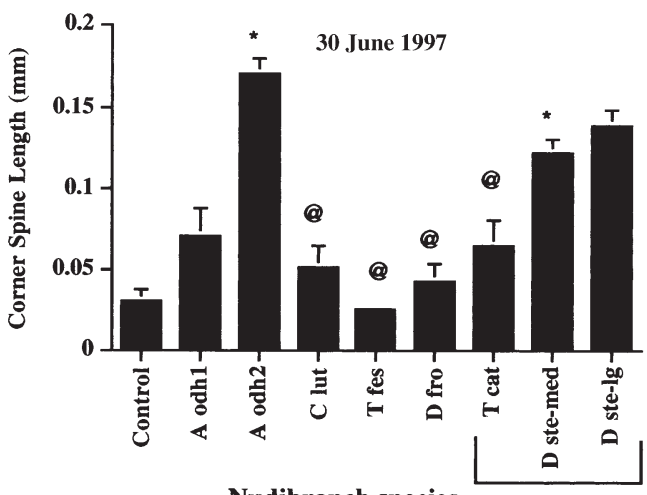

Nudibranch species

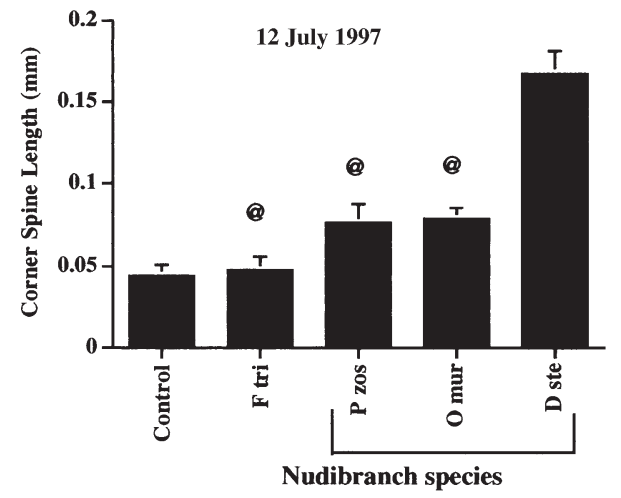

Fig. 2. Corner spines induced by chemical cues from different nudibranch species. Each graph represents a separate experiment. * Significantly different (KruskalWallis test, family alpha level $\mathrm{p}<0.05$ after Bonferroni correction) from the non-stimulus control (filtered water or Lacuna vincta chemical cues, designated 'Control' in the graphs); @Significantly different from the large-stimulus control (Doridella steinbergae chemical cues). Non-stimulus and large-stimulus controls were always significantly different from each other. Error bars indicate $1 \mathrm{SE}$. Nudibranch species are arrayed along the $x$-axis. Independent trials of the same species in the same week are listed as 1,2. Nudibranch species have been ordered on the $x$-axis in an attempt to reflect increasing probability of predation on Membranipora membranacea, from left to right. Brackets indicate nudibranchs that feed on $M$. membranacea, and thus are predicted to induce spines

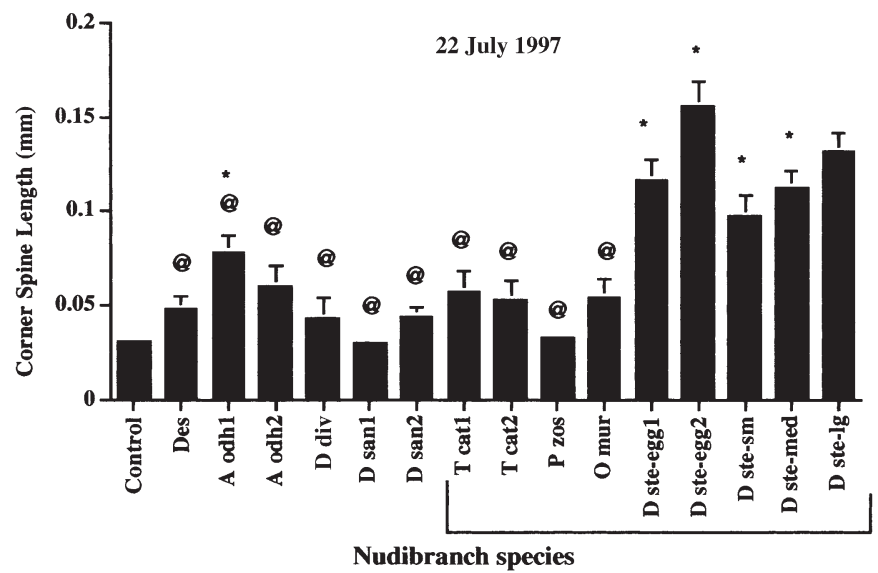

A odh: Archidoris odhneri; C lut: Cadlina luteomarginata; C sp: Coryphella sp. D alb: Dirona albolineata; D fro: Dendronotus frondosus; D san: Discodoris sandiegensis; D div: Dendronotus diversicolor; D ste: Doridella steinbergae; Des: Dessication treatment; egg: $D$. steinbergae egg mass treatment; F tri: Flabellina trilineata; -lg: Large D. steinbergae; -med: Medium D. steinbergae; O mur: Onchidoris muricata; P cra: Phidiana crassicornis; P zos: Polycera zosterae; -sm: Small D. steinbergae; T cat: Triopha catalinae; T fes: Tritonia festiva 

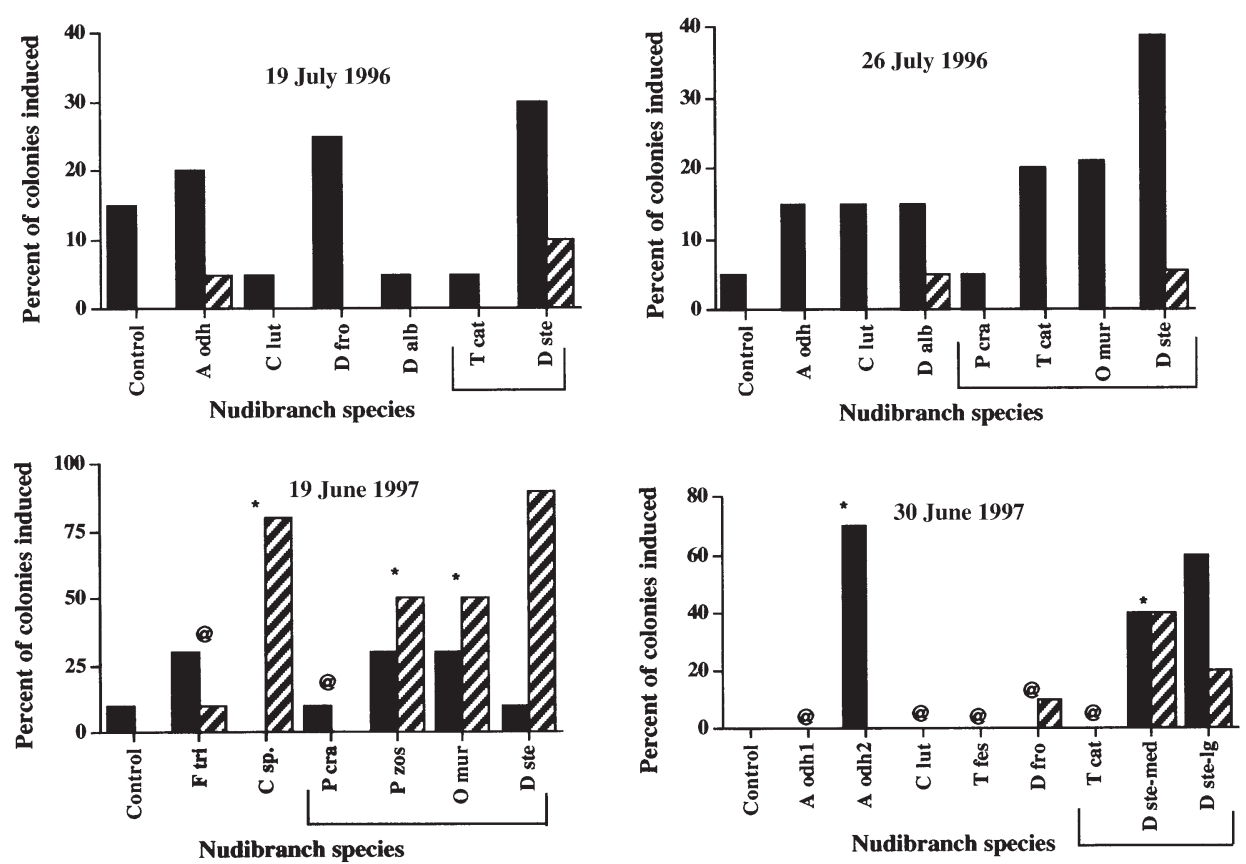

12 July 1997
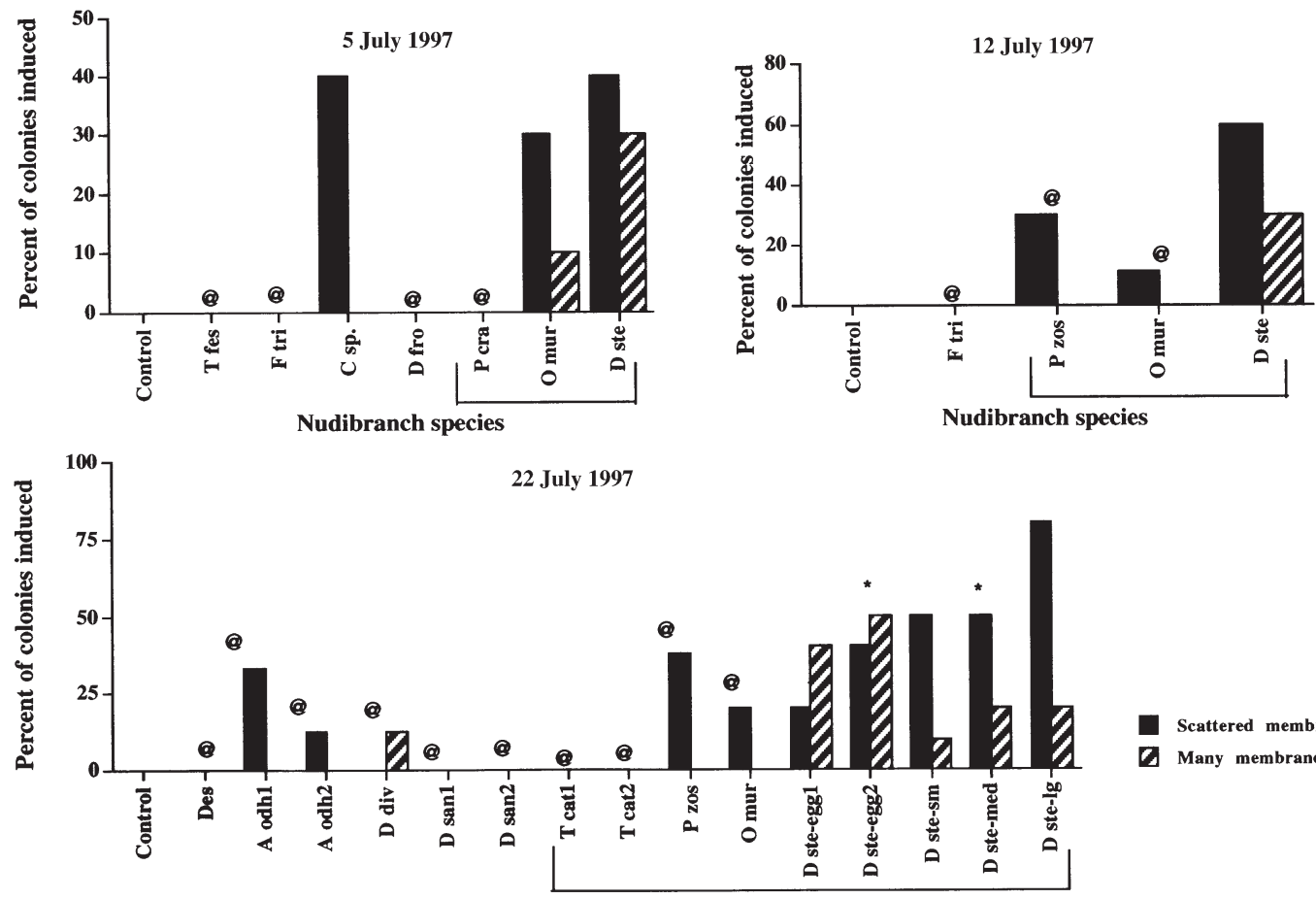

Scattered membranous spines

Many membranous spines

\section{Nudibranch species}

(Fig. 2, Table 2) or membranous (Fig. 3, Table 2) spines. Dendronotus diversicolor (tested once), Tritonia festiva (tested twice), Discodoris sandiegensis (tested twice), Dendronotus frondosus (tested 3 times), Flabellina trilineata (tested 3 times), and the desiccation treatment (tested once) did not induce either spine type.

Other nudibranch species varied in their ability to induce corner spines (Fig. 2, Table 2). Cadlina luteo-
Fig. 3. Membranous spines induced by chemical cues in each weekly experiment. The percentage of colonies showing scattered and extreme spine induction (coded 1 and 2) is displayed. *Membranous spine induction was significantly different (Wilcoxon rank sum or Fisher's exact test, family alpha level $\mathrm{p}<0.05$ after Bonferroni correction) from the non-stimulus control (filtered water or Lacuna vincta chemical cues, designated 'Control' in the graphs); @Spine induction significantly different from the large-stimulus control (Doridella steinbergae chemical cues). See Fig. 2 for species abbreviations. Positive and negative controls were significantly different from each other in all but the 2 1996 trials 
Table 2. p-values and Mann Whitney $U$ statistics of corner and membranous spine comparisons. Corner spine data were analyzed using Kruskal-Wallis tests $(\mathrm{df}=1)$. Membranous spine data with 3 categories were analyzed with Wilcoxon rank sum tests $(\mathrm{df}=2)$; membranous spine data with 2 categories were analyzed using Fisher's exact tests $(\mathrm{df}=1) .{ }^{*}$ Tests showing significance at the $95 \%$ family confidence level after Bonferroni adjustments; ND: The number of colonies in each category was the same for the test treatment as the control. Numbers in the nudibranch species column indicate that multiple trials of the same species were run in the same week. Nudibranch species are listed in increasing order of predation threat to Membranipora membranacea

\begin{tabular}{|c|c|c|c|c|c|c|c|c|c|}
\hline \multirow[t]{3}{*}{ Nudibranch species } & \multirow{3}{*}{$\begin{array}{l}\text { Test } \\
\text { date }\end{array}$} & \multicolumn{4}{|c|}{ Corner spine data } & \multicolumn{4}{|c|}{ Membranous spine data } \\
\hline & & \multicolumn{2}{|c|}{$\begin{array}{l}\text { vs Non-stimulus } \\
\text { control }\end{array}$} & \multicolumn{2}{|c|}{$\begin{array}{l}\text { vs Large-stimulus } \\
\text { control }\end{array}$} & \multicolumn{2}{|c|}{$\begin{array}{l}\text { vs Non-stimulus } \\
\text { control }\end{array}$} & \multicolumn{2}{|c|}{$\begin{array}{l}\text { vs Large-stimulus } \\
\text { control }\end{array}$} \\
\hline & & $\begin{array}{c}\text { Mann } \\
\text { Whitney } \\
U\end{array}$ & p-value & $\begin{array}{c}\text { Mann } \\
\text { Whitney } \\
U\end{array}$ & p-value & $\begin{array}{c}\text { Mann } \\
\text { Whitney } \\
U\end{array}$ & $\mathrm{p}$-value & $\begin{array}{c}\text { Mann } \\
\text { Whitney } \\
U\end{array}$ & $\mathrm{p}$-value \\
\hline \multicolumn{10}{|l|}{ Benign } \\
\hline Archidoris odhneri & 19 July 96 & 74.5 & $<0.001^{*}$ & 273 & 0.047 & 221.5 & $>0.05$ & 231 & $>0.05$ \\
\hline & 26 July 96 & 135.5 & $>0.05$ & 335 & $<0.001^{*}$ & 220 & $>0.05$ & 234.5 & 0.0386 \\
\hline (1) & 30 June 97 & 19 & $>0.05$ & 69 & 0.01 & ND & $>0.05$ & 8 & $0.001^{*}$ \\
\hline (2) & 30 June 97 & 0 & $<0.001^{*}$ & 25.5 & $>0.05$ & 85 & $0.0015^{*}$ & 38 & $>0.05$ \\
\hline (1) & 22 July 97 & 8.5 & $0.003^{*}$ & 82 & $0.002^{*}$ & 60 & $>0.05$ & 12 & $0.0018^{*}$ \\
\hline$(2)$ & 22 July 97 & 19 & $>0.05$ & 78 & $<0.001^{*}$ & 45 & $>0.05$ & 4 & $0.0002^{*}$ \\
\hline Cadlina luteomarginata & 19 July 96 & 139.5 & 0.083 & 332.5 & $<0.001^{*}$ & 180 & $>0.05$ & 271 & 0.0078 \\
\hline & 26 July 96 & 90.5 & $0.003^{*}$ & 332 & $<0.001^{*}$ & 220 & $>0.05$ & 234.5 & 0.0386 \\
\hline & 30 June 97 & 25 & $>0.05$ & 93 & $0.001^{*}$ & ND & $>0.05$ & 10 & $0.0004^{*}$ \\
\hline Dendronotus diversicolor & 22 July 97 & 31.5 & $>0.05$ & 77 & $<0.001^{*}$ & 45 & $>0.05$ & 9 & $0.0003^{*}$ \\
\hline Tritonia festiva & $\begin{array}{l}30 \text { June } 97 \\
5 \text { July } 97\end{array}$ & $\begin{array}{l}52.5 \\
48.5\end{array}$ & $\begin{array}{l}>0.05 \\
>0.05\end{array}$ & $\begin{array}{l}100 \\
100\end{array}$ & $\begin{array}{l}<0.001^{*} \\
<0.001^{*}\end{array}$ & $\begin{array}{l}\text { ND } \\
\text { ND }\end{array}$ & $\begin{array}{l}>0.05 \\
>0.05\end{array}$ & $\begin{array}{l}10 \\
15\end{array}$ & $\begin{array}{l}0.0004^{*} \\
0.0015^{*}\end{array}$ \\
\hline $\begin{array}{l}\text { Discodoris } \\
\text { sandiegensis }\end{array}$ & $\begin{array}{l}\text { 22 July } 97 \\
\text { 22 July } 97\end{array}$ & $\begin{array}{l}42 \\
17.5\end{array}$ & $\begin{aligned} &> 0.05 \\
& 0.043\end{aligned}$ & $\begin{array}{l}80 \\
80\end{array}$ & $\begin{array}{l}<0.001^{*} \\
<0.001^{*}\end{array}$ & $\begin{array}{l}\text { ND } \\
\text { ND }\end{array}$ & $\begin{array}{l}>0.05 \\
>0.05\end{array}$ & $\begin{array}{l}100 \\
100\end{array}$ & $\begin{array}{l}0^{*} \\
0^{*}\end{array}$ \\
\hline Dendronotus frondosus & $\begin{array}{l}\text { 19 July } 96 \\
\text { 30 June } 97 \\
5 \text { July } 97\end{array}$ & $\begin{array}{r}157.5 \\
26.5 \\
51.5\end{array}$ & $\begin{array}{l}>0.05 \\
>0.05 \\
>0.05\end{array}$ & $\begin{array}{l}371 \\
94.5 \\
100\end{array}$ & $\begin{array}{l}<0.001^{*} \\
<0.001^{*} \\
<0.001^{*}\end{array}$ & $\begin{array}{r}220 \\
55 \\
\text { ND }\end{array}$ & $\begin{array}{l}>0.05 \\
>0.05 \\
>0.05\end{array}$ & $\begin{array}{r}235 \\
18 \\
15\end{array}$ & $\begin{array}{l}>0.05 \\
0.0027^{*} \\
0.0015^{*}\end{array}$ \\
\hline Coryphella sp. & $\begin{array}{l}19 \text { June } 97 \\
5 \text { July } 97\end{array}$ & $\begin{array}{l}7.5 \\
9\end{array}$ & $\begin{array}{l}0.001^{*} \\
0.002^{*}\end{array}$ & $\begin{array}{l}38.5 \\
83.5\end{array}$ & $\begin{array}{c}>0.05 \\
0.011\end{array}$ & $\begin{array}{l}11 \\
70\end{array}$ & $\begin{array}{l}0.0004^{*} \\
0.0433\end{array}$ & $\begin{array}{l}56 \\
29\end{array}$ & $\begin{array}{l}>0.05 \\
>0.05\end{array}$ \\
\hline Flabellina trilineata & $\begin{array}{l}\text { 19 June } 97 \\
5 \text { July } 97 \\
12 \text { July } 97\end{array}$ & $\begin{array}{l}22 \\
62 \\
32.5\end{array}$ & $\begin{aligned} & 0.034 \\
> & 0.05 \\
> & 0.05\end{aligned}$ & $\begin{array}{c}90.5 \\
100 \\
80\end{array}$ & $\begin{aligned} & 0.002^{*} \\
&<0.001^{*} \\
&<0.001^{*}\end{aligned}$ & $\begin{array}{l}34.5 \\
\text { ND } \\
\text { ND }\end{array}$ & $\begin{array}{l}>0.05 \\
>0.05 \\
>0.05\end{array}$ & $\begin{array}{r}93 \\
15 \\
4\end{array}$ & $\begin{array}{l}0.0002^{*} \\
0.0015^{*} \\
0.0002^{*}\end{array}$ \\
\hline Dirona albolineata & $\begin{array}{l}19 \text { July } 96 \\
26 \text { July } 96\end{array}$ & $\begin{array}{r}83.5 \\
126.5\end{array}$ & $\begin{array}{l}0.001^{*} \\
0.045\end{array}$ & $\begin{array}{l}291.5 \\
326\end{array}$ & $\begin{array}{c}0.013 \\
<0.001^{*}\end{array}$ & $\begin{array}{l}180 \\
169.5\end{array}$ & $\begin{array}{l}>0.05 \\
>0.05\end{array}$ & $\begin{array}{l}271 \\
222\end{array}$ & $\begin{aligned} & 0.0078 \\
> & 0.05\end{aligned}$ \\
\hline \multicolumn{10}{|l|}{ Predator } \\
\hline Phidiana crassicornis & $\begin{array}{l}\text { 26 July } 96 \\
19 \text { June } 97 \\
5 \text { July } 97\end{array}$ & $\begin{array}{l}167.5 \\
29 \\
37.5\end{array}$ & $\begin{array}{l}>0.05 \\
>0.05 \\
>0.05\end{array}$ & $\begin{array}{c}337.5 \\
94.5 \\
100\end{array}$ & $\begin{array}{l}<0.001^{*} \\
<0.001^{*} \\
<0.001^{*}\end{array}$ & $\begin{array}{r}200 \\
50 \\
\text { ND }\end{array}$ & $\begin{array}{l}>0.05 \\
>0.05 \\
>0.05\end{array}$ & $\begin{array}{l}251.5 \\
99.5 \\
15\end{array}$ & $\begin{array}{l}0.0051 \\
0^{*} \\
0.0015^{*}\end{array}$ \\
\hline Triopha catalinae & $\begin{array}{l}19 \text { July } 96 \\
\text { 26 July } 96 \\
\text { 30 June } 97 \\
22 \text { July } 97 \\
22 \text { July } 97\end{array}$ & $\begin{array}{l}132 \\
76.5 \\
15 \\
22 \\
20\end{array}$ & $\begin{array}{c}>0.05 \\
<0.001^{*} \\
0.024 \\
0.033 \\
0.039\end{array}$ & $\begin{array}{l}311 \\
304.5 \\
72 \\
95 \\
87.5\end{array}$ & $\begin{array}{r}0.003^{*} \\
<0.001^{*} \\
0.004^{*} \\
<0.001^{*} \\
<0.001^{*}\end{array}$ & $\begin{array}{l}220 \\
230 \\
\text { ND } \\
\text { ND } \\
\text { ND }\end{array}$ & $\begin{array}{l}>0.05 \\
>0.05 \\
>0.05 \\
>0.05 \\
>0.05\end{array}$ & $\begin{array}{r}262 \\
226 \\
8 \\
100 \\
100\end{array}$ & $\begin{array}{l}\quad 0.0217 \\
>0.05 \\
0.001^{*} \\
0^{*} \\
0^{*}\end{array}$ \\
\hline Polycera zosterae & $\begin{array}{l}19 \text { June } 97 \\
12 \text { July } 97 \\
22 \text { July } 97\end{array}$ & $\begin{array}{l}1.5 \\
19 \\
32.5\end{array}$ & $\begin{array}{c}<0.001^{*} \\
0.018 \\
>0.05\end{array}$ & $\begin{array}{l}57 \\
97 \\
80\end{array}$ & $\begin{array}{l}>0.05 \\
<0.001^{*} \\
<0.001^{*}\end{array}$ & $\begin{array}{l}12.5 \\
\mathrm{ND} \\
25\end{array}$ & $\begin{aligned} & 0.0013^{*} \\
> & 0.05 \\
> & 0.05\end{aligned}$ & $\begin{array}{l}71 \\
15.5 \\
68\end{array}$ & $\begin{array}{l}0.0488 \\
0.004^{*} \\
0.0038^{*}\end{array}$ \\
\hline Onchidoris muricata & $\begin{array}{l}26 \text { July } 96 \\
\text { 19 June } 97 \\
5 \text { July } 97 \\
\text { 12 July } 97 \\
22 \text { July } 97\end{array}$ & $\begin{array}{l}2 \\
9.5 \\
6 \\
15.5 \\
16\end{array}$ & $\begin{aligned} &<0.001^{*} 0.002^{*} \\
&<0.001^{*} \\
& 0.015 \\
& 0.01\end{aligned}$ & $\begin{array}{l}206 \\
56.5 \\
83.5 \\
88 \\
95\end{array}$ & $\begin{aligned} &> 0.05 \\
&> 0.05 \\
& 0.011 \\
&<0.001^{*} \\
&<0.001^{*}\end{aligned}$ & $\begin{array}{c}220.5 \\
12.5 \\
30 \\
\text { ND } \\
40\end{array}$ & $\begin{array}{l}>0.05 \\
0.0013^{*} \\
0.0433 \\
>0.05 \\
>0.05\end{array}$ & $\begin{array}{c}213 \\
71 \\
67.5 \\
8 \\
92\end{array}$ & $\begin{aligned}> & 0.05 \\
& 0.0488 \\
> & 0.05 \\
& 0.0007^{*} \\
& 0.0002^{*}\end{aligned}$ \\
\hline Small Doridella & 22 July 97 & 0 & $<0.001^{*}$ & 78.5 & 0.031 & 20 & 0.0054 & 71 & 0.0302 \\
\hline Medium Doridella & $\begin{array}{l}30 \text { June } 97 \\
22 \text { July } 97\end{array}$ & $\begin{array}{l}0 \\
0\end{array}$ & $\begin{array}{l}<0.001^{*} \\
<0.001^{*}\end{array}$ & $\begin{array}{l}66.5 \\
65.5\end{array}$ & $\begin{array}{l}>0.05 \\
>0.05\end{array}$ & $\begin{array}{l}10 \\
15\end{array}$ & $\begin{array}{l}0.0004^{*} \\
0.0015^{*}\end{array}$ & $\begin{array}{l}42 \\
62\end{array}$ & $\begin{array}{l}>0.05 \\
>0.05\end{array}$ \\
\hline $\begin{array}{ll}\text { Doridella } \\
\text { eggs }\end{array}$ & $\begin{array}{l}22 \text { July } 97 \\
22 \text { July } 97\end{array}$ & $\begin{array}{l}0 \\
0\end{array}$ & $\begin{array}{l}<0.001^{*} \\
<0.001^{*}\end{array}$ & $\begin{array}{l}60 \\
33.5\end{array}$ & $\begin{array}{l}>0.05 \\
>0.05\end{array}$ & $\begin{array}{l}80 \\
95\end{array}$ & $\begin{array}{l}0.0054 \\
0.0001^{*}\end{array}$ & $\begin{array}{l}44 \\
61\end{array}$ & $\begin{array}{l}>0.05 \\
>0.05\end{array}$ \\
\hline $\begin{array}{l}\text { Abiotic } \\
\text { Desiccation }\end{array}$ & 22 July 97 & 25 & $>0.05$ & 98 & $<0.001^{*}$ & ND & $>0.05$ & 100 & $0^{*}$ \\
\hline
\end{tabular}


lus control, but in another trial (26 July 96), this species did not induce spines. Dirona albolineata (which does not feed on Membranipora membranacea but does eat other bryozoans) was tested in only the two 1996 experiments where responses to the large-stimulus and non-stimulus controls did not differ statistically. Therefore, no definitive conclusions can be drawn about $D$. albolineata's ability to induce membranous spines. However, in the trial with corner spine induction, D. albolineata did not induce many long membranous spines (a score of 2) in any colony and induced only scattered membranous spines (a score of 1) in 1 of 20 colonies (compared with 2 scores of 2 and 6 scores of 1 for the large-stimulus control; zero scores of 2 and 3 scores of 1 for the non-stimulus control). Thus, we suspect that $D$. albolineata does not usually induce membranous spines.

Archidoris odhneri, which does not usually co-occur with the bryozoan, induced significant corner spines in 3 of 6 trials, and in 3 trials the spines induced by this species were indistinguishable from those induced by Doridella steinbergae. In 1 trial, A. odhneri induced membranous spines that were indistinguishable from those in the large-stimulus control (D. steinbergae), but this species did not induce membranous spines in its other 3 trials. Coryphella sp. (tested twice), never observed to feed on Membranipora membranacea, always induced corner spines that were statistically indistinguishable from those in the large-stimulus control (Fig. 2, Table 2). Coryphella sp. induced significant production of membranous spines in 1 trial (19 June 97); but in another trial (5 July 97), the membranous spines produced were not significantly different from those in either of the controls.

Induction by predatory nudibranchs

Polycera zosterae induced significant amounts of corner and membranous spines only once in 3 trials (19 June 97), but in that 1 trial both spine types were produced to the same extent as those induced by Doridella steinbergae. In 3 of 5 trials, Onchidoris muricata induced corner spines that were indistinguishable from those of the large-stimulus control (26 July 96, 19 June 97, and 5 July 97), but in 2 other trials (12 July 97, 22 July 97) this species did not induce spines. For membranous spine induction, O. muricata induced a significant response in 1 trial (19 June 97), responses indistinguishable from either control in 2 trials (26 July 96, 5 July 97), and no membranous spines in 2 trials (12 July 97, 22 July 97).

Triopha catalinae induced significantly long corner spines in only 1 of 5 trials, and in that trial the spines were significantly shorter than those induced by
Doridella steinbergae (the large-stimulus control). T. catalinae never induced membranous spines (Fig. 3, Table 2). Phidiana crassicornis (tested 3 times) never induced corner or membranous spines (Figs 2 \& 3, Table 2).

\section{Phylogenetic basis of the cue}

Membranipora membranacea corner spine production was stimulated by inducer from a wide taxonomic range of nudibranch species, spanning 6 families and 3 suborders. The production of membranous spines was triggered by cues from nudibranchs in 4 families and 2 suborders. Because some nudibranchs within the same suborder as Doridella steinbergae (Doridacea) did not induce either type of spine (e.g. Discodoris sandiegensis), while nudibranchs from other suborders did induce both types of spines (e.g. Coryphella sp.), the cue inducing spine production is not phylogenetically based.

\section{Correlation between the production of corner and membranous spines}

As predicted, combined across all nudibranch species and all experimental dates, there is a significant correlation $\left(\mathrm{r}^{2}=0.480, \mathrm{df}=58, \mathrm{p}<0.01\right)$ between average length of corner spines in each treatment (averaged across all colonies) and the percentage of colonies in that treatment producing many long membranous spines (score of 2) (Fig. 4). Observing each experimental week individually, there were significant correlations between corner and membranous spines in 5 of the 7 weeks (19 July 96: $\mathrm{r}^{2}=0.762$, df $=5, \mathrm{p}<$

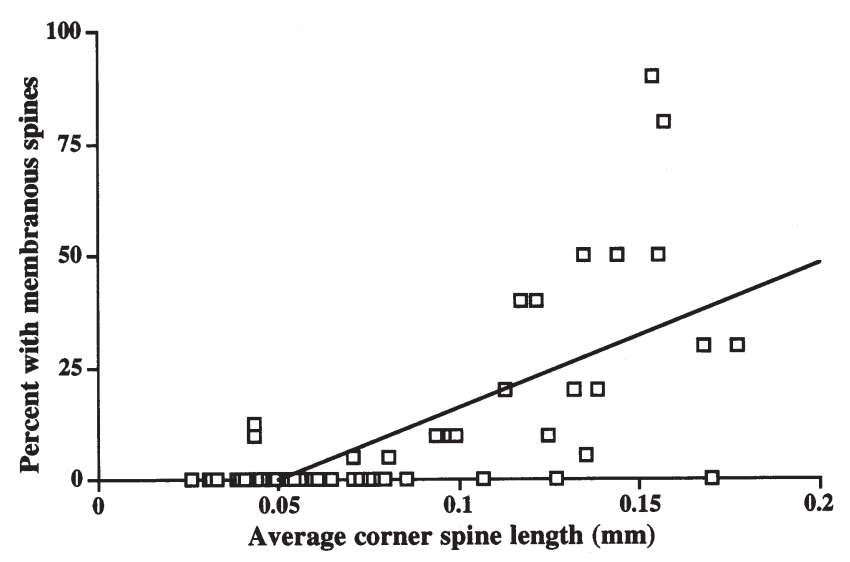

Fig. 4. Correlation between average length of corner spines and percentage of colonies with membranous spines is shown with all experimental dates and all nudibranch species included. The line represents the equation with the best fit to the data: $y=323.648 x-16.137, \mathrm{r}^{2}=0.480, \mathrm{df}=58, \mathrm{p}<0.01$ 
0.05; 19 June 97: $\mathrm{r}^{2}=0.885, \mathrm{df}=5, \mathrm{p}<0.05 ; 5$ July 97 : $\mathrm{r}^{2}=0.767, \mathrm{df}=6, \mathrm{p}<0.05 ; 12$ July 97: $\mathrm{r}^{2}=0.901, \mathrm{df}=3$, $\mathrm{p}<0.05$; 22 July 97: $\mathrm{r}^{2}=0.734$, df $\left.=14, \mathrm{p}<0.05\right)$. In 1 (26 July 96) of the 2 experiments where corner and membranous spines were not correlated (26 July 96: $r^{2}=0.172, d f=6, p>0.05 ; 30$ June 97: $r^{2}=0.189, d f=7$, $\mathrm{p}>0.05)$, the large-stimulus control did not induce significantly more membranous spines than the nonstimulus control.

All trials inducing significant quantities of membranous spines induced corner spines, but corner spines could be induced without membranous spines. Archidoris odhneri, Coryphella sp., Onchidoris muricata, Triopha catalinae, Cadlina luteomarginata, small Doridella steinbergae, and D. steinbergae egg masses induced, in at least 1 trial, corner spines that were significantly longer than those in the non-stimulus control (although not necessarily as long as the large-stimulus control) without inducing significant amounts of membranous spines.

\section{Possible function of the cue for Doridella steinbergae}

All size classes (large, tested twice, by definition the large-stimulus control; medium, tested twice; small, tested once) and egg masses (tested twice) of Doridella steinbergae induced corner spines that were statistically longer than those induced by the non-stimulus control and indistinguishable from those induced by the large-stimulus control (Fig. 2, Table 2). Large and medium $D$. steinbergae always induced significant numbers of long membranous spines; the latter induced greater amounts of membranous spines than the former in 1 trial (30 June 97). Small D. steinbergae induced a membranous spine response that was indistinguishable from that in both the non-stimulus and large-stimulus controls. D. steinbergae egg masses (tested twice) induced more long membranous spines (score of 2) than the large-stimulus control. However, in only 1 of the 2 egg mass trials was the overall spine production significantly greater than that of the nonstimulus control; in the other trial the overall production of spines was indistinguishable from that of either control.

\section{DISCUSSION}

\section{Specificity of the cue}

Membranipora membranacea responds to chemical cues from multiple predatory nudibranch species by producing defensive spines. We predicted that, because of the energetic and opportunity costs of producing spines in the wrong environment (Harvell 1986, Moran 1992, Grünbaum 1997), M. membranacea would show a specific induction response limited to Doridella steinbergae and a few other bryozoan predators. Five non-predatory nudibranch species (including some from the same suborder as D. steinbergae) and the desiccation treatment never induced either corner or membranous spines. However, more than half (8 of 14) of the nudibranch species tested in these experiments induced corner spines (Table 3); of the species that induced corner spines, only 4 of the 8 were predators of $M$. membranacea. Five of the 14 species tested induced membranous spines; 3 were predators of M. membranacea. For both spine types, a number of species did not consistently induce spines. M. membranacea's sensitivity to chemical cues did not always match its apparent level of risk; this mismatch was not due to a phylogenetic basis of the cue. But, despite this apparent lack of specificity in ability to respond to a range of nudibranchs, no nudibranch species consistently induced both types of spines of the same magnitude as Doridella steinbergae, a trophic specialist on M. membranacea.

Coryphella sp. always induced corner spines and even induced membranous spines in 1 trial. This species is sympatric with Membranipora membranacea, but should not be a threat to the bryozoan, as it feeds on hydroids. Cadlina luteomarginata, Dirona albolineata, and Archidoris odhneri also induced corner spines in some trials, although none of these species is reported to feed on $M$. membranacea. However, we conclude that $C$. luteomarginata does not normally induce spines. The only trial (of 3) showing spine induction by $C$. luteomarginata still resulted in significantly shorter corner spines than those in the largestimulus control, and membranous spines were never induced. Interestingly, A. odhneri induced longer corner spines than the large-stimulus control and significant membranous spines in 1 trial (30 June 97), but usually did not induce spines. This large dorid eats sponges and is usually found in deeper water than M. membranacea at this site (Iyengar pers. obs.). In the trials where spines were produced, copious amounts of mucus (from $A$. odhneri) passed through the coarse filter and were added with the inducer. It is possible that the mucus stressed the bryozoans and, in response to the stress rather than to a specific chemical cue, the bryozoans produced spines. $M$. membranacea is not known to produce spines as a generalized stress response but it has produced forked spines in still water (Harvell \& Trager unpubl. data). Alternatively, A. odhneri, in the same suborder as D. steinbergae, may be chemically similar to D. steinbergae. However, the latter explanation is unlikely, as spine induction by this species was irregular. 
Table 3. Overview of spine induction abilities of chemical cues from the nudibranch species tested in these experiments. A nudibranch species was predicted to induce spines if it was a predator of Membranipora membranacea and predicted not to induce spines if it was not a predator. The numbers in parentheses indicate what proportion of the trials using that species showed induction of that type of spine

\begin{tabular}{|c|c|c|c|}
\hline Nudibranch species & Predicted to induce spines? & Induced corner spines? & Induced membranous spines? \\
\hline \multicolumn{4}{|l|}{ Benign } \\
\hline $\begin{array}{l}\text { Lacuna vincta } \\
\text { (Non-stimulus control) }\end{array}$ & No & no $(7 / 7)$ & no $(7 / 7)$ \\
\hline Archidoris odhneri & No & Yes $(3 / 6)$ & Yes $(1 / 6)$ \\
\hline Cadlina luteomarginata & No & Yes $(1 / 3)$ & No $(0 / 3)$ \\
\hline Dendronotus diversicolor & No & No $(0 / 1)$ & No $(0 / 1)$ \\
\hline Tritonia festiva & No & No $(0 / 2)$ & No $(0 / 2)$ \\
\hline Discodoris sandiegensis & No & No $(0 / 2)$ & No $(0 / 2)$ \\
\hline Dendronotus frondosus & No & No $(0 / 3)$ & No $(0 / 3)$ \\
\hline Coryphella sp. (rufescens?) & No & Yes $(2 / 2)$ & Yes $(1 / 2)$ \\
\hline Flabellina trilineata & No & No $(0 / 3)$ & No $(0 / 3)$ \\
\hline Dirona albolineata & No & Yes $(1 / 2)$ & No $(0 / 2)$ \\
\hline \multicolumn{4}{|l|}{ Predator } \\
\hline Phidiana crassicornis & Yes & No $(0 / 3)$ & No $(0 / 3)$ \\
\hline Triopha catalinae & Yes & Yes $(1 / 5)$ & No $(0 / 5)$ \\
\hline Polycera zosterae & Yes & Yes $(1 / 3)$ & Yes $(1 / 3)$ \\
\hline Onchidoris muricata & Yes & Yes $(3 / 5)$ & Yes $(1 / 5)$ \\
\hline Doridella egg masses & No & Yes $(2 / 2)$ & Yes $(1 / 2)$ \\
\hline small Doridella & no (if cue is mating pheromone) & Yes $(1 / 1)$ & No $(0 / 1)$ \\
\hline medium Doridella & Yes & Yes $(2 / 2)$ & Yes $(2 / 2)$ \\
\hline $\begin{array}{l}\text { Doridella steinbergae } \\
\text { (Large-stimulus control) }\end{array}$ & Yes & Yes $(7 / 7)$ & Yes $(5 / 7)$ \\
\hline
\end{tabular}

Also surprising, Membranipora membranacea did not always produce spines against predators. Doridella steinbergae, the specialist predator, always induced corner spines and usually induced membranous spines. However, Polycera zostera and Onchidoris muricata are consistent predators but varied in their ability to induce corner and membranous spines. The variation in response to $P$. zosterae could have been caused by differences in the concentration of inducer. When $P$. zosterae induced corner and membranous spines, a nudibranch concentration of $9 \mathrm{l}^{-1}$ was used to prepare inducer; when a nudibranch concentration of $2 \mathrm{l}^{-1}$ was used (due to seasonal difficulty in finding individuals), no spines were induced. Thus, $P$. zosterae can induce spines in $M$. membranacea, but there may be a threshold of induction that lies somewhere between 2 and $9 \mathrm{l}^{-1}$. Triopha catalinae produced corner spines in only 1 of 4 trials and never produced significant membranous spines. Phidiana crassicornis never induced either spine type.

\section{Damage inflicted by predators of Membranipora membranacea}

There is a fundamental difference in the way Doridella steinbergae, Onchidoris muricata, Polycera zos- terae, Phidiana crassicornis, and Triopha catalinae feed that may explain their differential spine activation. $O$. muricata and $P$. zosterae are similar in size to $D$. steinbergae; T. catalinae and P. crassicornis are much larger. D. steinbergae feeds by slitting the membrane of an individual bryozoan zooid and sucking out the polypide, leaving the empty zoecium behind. Corner and membranous spines cause difficulty for the nudibranchs by discouraging proper mouth positioning for feeding, and so are an effective defense (McBeth pers. comm., cited in Yoshioka 1982). After a predation event, the damage caused by $D$. steinbergae, O. muricata, and $P$. zosterae looks similar: empty zoecia with side walls in place. Thus, spines, shown to slow the feeding of $D$. steinbergae, are probably also effective against $O$. muricata and $P$. zosterae. T. catalinae steamshovels through a colony, leaving wide swathes of cleared kelp behind. Because T. catalinae is large relative to the zooids, it is likely that neither type of bryozoan spine can deter this predator. Indeed, Yoshioka (1982) predicted that spines would offer little protection against predators that consumed the entire zooid structure of $M$. membranacea. P. crassicornis causes minimal damage to $M$. membranacea, feeding on the pre-zooids at the edge of the colony. Pre-zooids are not able to produce spines, so deploying the spination defense would be ineffective against $P$. crassicornis. 


\section{Correlation between the production of corner and membranous spines}

The length of corner spines and the proportion of colonies with membranous spines were usually correlated. In cases where only 1 spine type was produced, it was always corner spines; membranous spines were always accompanied by corner spines. Decreasing size classes of Doridella steinbergae produced correspondingly fewer corner and membranous spines, to the point that small $D$. steinbergae induced corner spines but not membranous spines. Our results are consistent with the hypothesis that a lower threshold of cue is required to trigger corner than membranous spines and confirm Harvell's (1998) conclusion that membranous spines are a more definitive defense response than corner spines. The deterrence of corner spines alone has never been tested, nor have the costs or benefits of defense been partitioned for the different spine types.

\section{Possible functions of the inducing cue for nudibranchs}

It has been proposed that cues inducing defenses are difficult for predators to obscure if they are constrained by processes critical to other functions in the predator's life (Adler \& Grünbaum 1999). In those cases, the predator cannot change the cue without detriment to another biological function. One such hypothesis is that the Doridella steinbergae cue inducing spines in Membranipora membranacea is a mating pheromone (Adler \& Grünbaum 1999). However, small (pre-reproductive), medium (possibly pre-reproductive), and large D. steinbergae, as well as D. steinbergae egg masses, all induced corner spines in these experiments. Egg masses, and medium and large D. steinbergae also induced membranous spines. Thus, the spine induction cue is not simply a mating pheromone-if it were, egg masses and pre-reproductives would not induce spines. This result is consistent with Nowlis's findings (1994) that $D$. steinbergae are insensitive to bryozoan spines during mating. If the inducing cue were a mating pheromone, the bryozoan would create costly defenses at a time when those defenses would be ignored because the nudibranchs were mating and not feeding. The induction cue(s) is also not a by-product of feeding on M. membranacea, as Phidiana crassicornis did not induce spines and Triopha catalinae rarely did. Because there were non-spine-inducing nudibranchs more closely related to $D$. steinbergae than Coryphella sp. (e.g. Discodoris sandiegensis), it is unlikely that the spine-inducing cue is phylogenetically determined. The identity of the D. steinbergae and other nudibranch induction cue(s) remains unknown. Elucidation of its chemical composition may aid in determining its function for $D$. steinbergae.

\section{Conclusions and future directions}

The ability to respond to changes in predator regimen may be important to the evolution of inducibility (Harvell \& Tollrian 1999). The specificity of cues that stimulate induced defenses is known for few systems (Tollrian \& Harvell 1999b). Besides the present study, specificity of induced morphological changes has been assessed only in cladocerans, protozoans, and barnacles (Kuhlman \& Heckmann 1985, Lively 1986, Dodson 1988, Dodson 1989, Tollrian \& Dodson 1999). These previous studies showed a good correspondence between predator cues and induced defenses, but in most cases only cues from predators were used (Lively 1986 is an exception). Our prediction of specificity was usually upheld as Membranipora membranacea showed the highest level of sensitivity for, and the largest induced response to, its most common and trophically specialized predator, Doridella steinbergae. However, the defense response was sometimes erroneously deployed. It can be concluded from these studies that diet (i.e. predators of $M$. membranacea) and method of feeding (slitting the membrane of individual zooids) are the most important predictors of species that can induce spines in $M$. membranacea. It is unknown whether the nudibranchs inducing spines in this study emitted the same chemical(s) or whether $M$. membranacea produces the same phenotypic response to multiple chemical cues.

Acknowledgements. This work was supported by an Edna Bailey Sussman summer fellowship grant to E.V.I. and NSF grant IBN 9408228 to C.D.H. We would like to thank Françoise Vermeylen for help with statistical analyses. This paper benefited from reviews by the Friday Harbor Laboratories reading group and 5 anonymous reviewers.

\section{LITERATURE CITED}

Adler FR, Grünbaum D (1999) Evolution of forager response to inducible defenses. In: Tollrian R, Harvell CD (eds) The ecology and evolution of inducible defenses. Princeton University Press, Princeton, p 259-285

Adler FR, Harvell CD (1990) Inducible defenses, phenotypic variability, and biotic environments. Trends Ecol Evol 5: $407-410$

Agrawal AA, Laforsch C, Tollrian R (1999) Transgenerational induction of defenses in animals and plants. Nature 401: $60-63$

Agrawal AA, Karban R, Colfer RG (2000) How leaf domatia and induced plant resistance affect herbivores, natural enemies, and plant performance. Oikos 89:70-80

Appleton RD, Palmer AR (1988) Water-borne stimuli released 
by predatory crabs an damaged prey induce more predator-resistant shells in a marine gastropod. Proc Natl Acad Sci USA 85:4387-4391

Baldwin IT (1996) Inducible defenses and population biology. Trends Ecol Evol 11:104-105

Behrens DW (1980) Pacific coast nudibranchs. Sea Challengers, Los Osos

Bickell LR (1978) Larval development, metamorphosis, and juvenile feeding of Doridella steinbergae (Lance) (Opisthobranchia: Nudibranchia). MS thesis, The University of Alberta, Edmonton

Bradshaw AD (1965) Evolutionary significance of phenotypic plasticity in plants. Adv Genet 13:115-155

Dodson SI (1988) The ecological role of chemical stimuli for zooplankton: Predator-avoidance behavior in Daphnia. Limnol Oceanogr 33:1431-1439

Dodson SI (1989) The ecological role of chemical stimuli for the zooplankton: Predator-induced morphology in Daphnia. Oecologia 78:361-367

Farmer WM (1980) Sea-slug gastropods. WM Farmer Enterprises, Tempe

Gaulin G, Dill L, Beaulieu J, Harris LG (1986) Predationinduced changes in growth form in a nudibranch-hydroid association. Veliger 28:389-393

Gilbert JJ (1966) Rotifer ecology and embryological induction. Science 151:1234-1237

Gilbert JJ, Stemberger RS (1984) Asplancha-induced polymorphism in the rotifer Keratella slacki. Limnol Oceanogr 29:1309-1316

Grünbaum D (1997) Hydromechanical mecahnisms of colony organization and cost of defense in an encrusting bryozoan, Membranipora membranacea. Limnol Oceanogr 42: $741-752$

Harvell CD (1984) Predator-induced defenses in a marine bryozoan. Science 224:1357-1359

Harvell CD (1986) The ecology and evolution of inducible defenses in a marine bryozoan: cues, costs, and consequences. Am Nat 128:810-823

Harvell CD (1990a) The ecology and evolution of inducible defenses. Q Rev Biol 65:323-340

Harvell CD (1990b) The evolution of inducible defenses. Parasitology 100(Suppl):S53-S61

Harvell CD (1991) Coloniality and inducible polymorphism. Am Nat 138:1-14

Harvell CD (1992) Inducible defenses and allocation shifts in a marine bryozoan. Ecology 73:1567-1576

Harvell CD (1994) The evolution of polymorphism in colonial invertebrates and in social insects. Q Rev Biol 69:155-18

Harvell CD (1998) Genetic variation and polymorphism in the inducible spines of a marine bryozoan. Evolution 52:80-86

Harvell CD, Tollrian R (1999) Why inducible defenses? In: Tollrian R, Harvell CD (eds) The ecology and evolution of inducible defenses. Princeton University Press, Princeton, p 3-9

Editorial responsibility: Otto Kinne (Editor),

Oldendorf/Luhe, Germany
Havel JE (1987) Predator-induced defenses: a review. In: Kerfoot WC, Sih A (eds) Predation: direct and indirect impacts on aquatic communities. University Press of New England, Hanover, p 263-278

Karban R, Myers JH (1989) Induced plant response to herbivory. Annu Rev Ecol Syst 20:331-348

Karban R, Baldwin IT (1997) Induced responses to herbivory. University of Chicago Press, Chicago

Kuhlman HW, Heckmann K (1985) Interspecific morphogens regulating predator-prey relationships in protozoa. Science 227:1347-1349

Leonard GH, Bertness MD, Yund PO (1999) Crab predation, waterborne cues, and inducible defenses in the blue mussel, Mytilus edulis. Ecology 80:1-14

Levins R (1963) Theory of fitness in a heterogeneous environment. II. Developmental flexibility and niche selection. Am Nat 97:75-90

Lively CM (1986) Predator-induced shell dimorphism in the acorn barnacle Chthamalus anisopoma. Evolution 40: $232-242$

Lively CM, Hazel WN, Schellenberger MJ, Michelson KS (2000) Predator-induced defense: variation for inducibility in an intertidal barnacle. Ecology 81:1240-1247

Lloyd DG (1984) Variation strategies of plants in heterogeneous environments. Biol J Linn Soc 21:357-385

McCollum SA, Van Buskirk J (1996) Costs and benefits of a predator-induced polyphenism in the grey treefrog Hyla chrysoscelis. Evolution 50:583-593

McDonald GR, Nybakken JW (1980) Guide to the nudibranchs of California. American Malacologists, Inc., Melbourne, FL

Moran NA (1992) The evolutionary maintenance of alternative phenotypes. Am Nat 139:971-989

Nowlis JP (1994) The causes and consequences of host preferences in marine gastropods. PhD thesis, Cornell University, Ithaca

Tollrian R, Dodson SI (1999) Inducible defenses in cladocera: Constraints, costs and multipredator environments. In: Tollrian R, Harvell CD (eds) The ecology and evolution of inducible defenses. Princeton University Press, Princeton, p 177-202

Tollrian R, Harvell CD (eds) (1999a) The ecology and evolution of inducible defenses. Princeton University Press, Princeton

Tollrian R, Harvell CD (1999b) The evolution of inducible defenses: current ideas. In: Tollrian R, Harvell CD (eds) The ecology and evolution of inducible defenses. Princeton University Press, Princeton, p 306-321

Yoshioka PM (1982) Predator-induced polymorphism in the bryozoan Membranipora membranacea (L.). J Exp Mar Biol Ecol 61:233-242

Zangerl AR, Arntz AM, Berenbaum MR (1997) Physiological price of an induced chemical defense: photosynthesis, respiration, biosynthesis, and growth. Oecologia 109: 433-441

Submitted: October 6, 2000; Accepted: February 15, 2001

Proofs received from author(s): January 4, 2002 